\title{
Agarose Gel
}

National Cancer Institute

\section{Source}

National Cancer Institute. Agarose Gel. NCI Thesaurus. Code C45308.

An electrophoresis gel composed of agarose dissolved in an aqueous buffer. 